$11-2020$

\title{
Navigating the Web of Informal Institutions When Investing in a Strange Land: Chinese Multinational Enterprises in Australia
}

\author{
Mingqiong Mike Zhang \\ Monash University, Melbourne, Australia \\ Ying Lu \\ Macquarie University, Sydney, Australia \\ Jiuhua Cherrie Zhu \\ Monash University, Melbourne, Australia \\ Hui Zhou \\ Hunan University, Changsha, Hunan, China
}

Follow this and additional works at: https://digitalcommons.newhaven.edu/americanbusinessreview

\section{Recommended Citation}

Zhang, Mingqiong Mike; Lu, Ying; Zhu, Jiuhua Cherrie; and Zhou, Hui (2020) "Navigating the Web of Informal Institutions When Investing in a Strange Land: Chinese Multinational Enterprises in Australia," American Business Review. Vol. 23 : No. 2 , Article 7.

DOI: 10.37625/abr.23.2.316-334

Available at: https://digitalcommons.newhaven.edu/americanbusinessreview/vol23/iss2/7 


\section{Navigating the Web of Informal Institutions When Investing in a Strange Land: Chinese Multinational Enterprises in Australia}

American Business Review Nov. 2020, Vol.23(2) $316-334$

(c) The Authors 2020, CC BY-NC

ISSN: 2689-8810 (Online) ISSN: 0743-2348 (Print)

\author{
Mingqiong Mike Zhang a , Ying Lu ${ }^{b}$, Jiuhua Cherrie Zhu a , and Hui Zhou ${ }^{c}$ \\ https://doi.org/10.37625/abr.23.2.316-334
}

\begin{abstract}
Multinational enterprises (MNEs) need to understand and handle various informal institutions in host countries to survive and succeed. How MNEs effectively manage informal institutional characteristics of host countries is an important question for both practitioners and scholars. This paper addresses this important but neglected topic based on an in-depth longitudinal qualitative study. It identifies some key informal institutions in Australia, examines how such institutional distinctiveness shapes the behaviour of Chinese expatriates and MNEs and how they handle such informal institutional differences between China and Australia. Our findings challenge some taken-for-granted assumptions regarding informal institutions in the literature and demonstrate that informal institutions of host countries significantly shape the behaviour of expatriates and firm-level strategies of MNEs.
\end{abstract}

\title{
KEYWORDS
}

Australia, China, Informal Institution, Longitudinal Qualitative Study, Multinational Enterprise

\section{INTRODUCTION}

According to institutionalism, organizations operate in the web of various intertwined institutions spun by social actors (Scott,2013). It is a consensus view that institutions matter. Institutional networks structure opportunities, generate social expectations and incentives, shape human behaviour and interaction, and determine transaction costs (North, 1990). Failing to comprehend institutions adequately and accurately could be costly for both individuals and organizations.

Multinational enterprises (MNEs) investing outside home countries as a 'stranger in a strange land' (Heilein,1961), need to comprehend and handle various formal and informal institutions so as to survive and succeed. Therefore, how MNEs effectively respond to and strategically manage formal and informal institutional characteristics of host countries is a central question for both practitioners and scholars. For that reason, scholars have shown a growing interest in institutional environment and how MNEs deal with the complex institutional context when operating overseas (e.g., Allen, Allen, \& Lange, 2018; Regnér \& Edman, 2014).

Nevertheless, comprehending formal and informal institutions of host countries can be a challenging task for MNEs. As North (1990, p.107) has noted, it might be less challenging to be precise about formal written rules, but it is not easy to be precise about informal institutions since we cannot see or touch such deep 'constructs of the human mind.' Given the tacit nature of informal institutions, it is not easy to identify, interpret, and measure them adequately and precisely (Sartor \& Beamish,2014;

\footnotetext{
a Monash University, Melbourne, Australia

${ }^{b}$ Macquarie University, Sydney, Australia

c Hunan University, Changsha, Hunan, China

Corresponding Author:

Zhang (mike.zhang@monash.edu)
} 
Wang, Lu, Soderlund, \& Chen,2018).In recent decades, scholars have paid more attention to the relationship between formal institutions (e.g., property rights, rule of law, and anti-trust regulation, etc.)and MNEs, but the relationship between informal institutions and MNEs has not attracted enough attention (Dau, Chacar, Lyles, \& Li,2018; Henisz \& Swaminathan, 2008; Regnér \& Edman, 2014; Sartor \& Beamish, 2014; Seyoum, 2011). Although the existing MNE literature is full of studies on cultures, culture and informal institution are not an identical construct (Dau et al., 2018; Helmke \& Levitsky, 2004, 2006; Redding, 2008; Seyoum, 2011). Consequently, since informal institution becomes tangled up with culture in the mainstream MNE literature, there are gaps in our understanding of the relationship between informal institution and MNEs. We do not have enough knowledge regarding the interactions between informal institutions and enterprise-level strategies of MNEs. How informal institutions shape the behaviour of MNEs and how MNEs respond to informal institutional variations in host countries have not been well understood (Henisz \& Swaminathan, 2008; Regnér \& Edman, 2014; Seyoum, 2011). However, informal institutions, as "rules in force" (Ostrom, 2005), structure social expectations and significantly shape business activities and transaction costs (Sartor \& Beamish, 2014). Both formal and informal institutions should be comprehensively integrated into the mainstream management studies (Wang et al., 2018).

The void in the literature informs this study to explore how MNEs learn to navigate the web of informal institutions in host countries so as to advance our understanding of interactions between informal institutions and MNEs. Differing from the mainstream MNE literature satisfied with examining the relationship between cultures and MNEs, this study goes beyond national cultures into informal institutions. It is also among limited MNE studies that empirically identify informal institutions of a host country and examine coping strategies of expatriates and MNEs. This enables our research to contribute to the literature in terms of both theoretical and practical implications.

Given that research on the internationalization of emerging economy multinational enterprises (EMNEs) is still in its infancy, the post-entry internationalization process of EMNEs has not received enough attention (Luo \& Zhang, 2016), it remains unclear how EMNEs handle informal institutions in host countries, especially in developed economies (Klossek, Linke, \&Nippa,2012). Therefore, based on an in-depth longitudinal qualitative study, this paper empirically examines the interaction of EMNEs (Chinese MNEs) investing in a developed country (Australia) with local informal institutional characteristics through exploring the following questions:

1. What are the major Australian informal institutions that shape the relationship between MNEs and local major stakeholders?

2. How do Chinese MNEs and their expatriates handle the informal institutional characteristics in Australia?

The remainder of this paper is structured as follows. Section two discusses the existing understanding of informal institutions and the relationships between formal and informal constraints, aiming to clarify the concept of informal institution. Section three elaborates on the existing studies on the relationship between informal institutions and MNEs, aspiring to make clear the trends and gaps in the literature. Section four discusses the methodological approach to data collection and analysis. Sections five and six present our findings of major Australian informal institutions and how Chinese MNEs manage the informal institutional environment. The paper is concluded by discussing findings, contributions, implications, and limitations, together with future research directions. 


\section{CLARIFYING INFORMAL INSTITUTIONS}

Institution is a widely used concept with different interpretations in the social sciences (Scott, 2013). For North (1991, p.97), institutions are "rules of the game"; for Orr and Scott (2008, p.565), institutions are "symbolic frameworks that provide guidelines for behaviour, and lend stability, regularity, and meaning to social life"; whereas Huntington (1969, p.12) defines institutions as "stable, valued, recurring patterns of behaviour".

Institutions as "humanly devised constraints that structure political, economic and social interaction" involve both formal and informal rules (North, 1990, p.97; Wang et al., 2018). Usually, formal institutions such as laws and regulations are consciously designed written rules enforced by the state; while informal institutions such as customs and patterns of action are usually tacit, taken for granted, and unconsciously followed (Zhang, 2016). Format (written or unwritten), design (consciously designed or unconsciously formed), and enforcement mechanism (enforced officially or non-officially) are major criteria used to draw a line between formal and informal institutions. Therefore, Helmke and Levitsky (2004, p.727) define informal institutions as "socially shared rules, usually unwritten, that are created, communicated, and enforced outside of officially sanctioned channels".

In the literature, the term informal institution has been applied to various non-codified and nonofficial phenomena such as taboos, customs, traditions, codes of conduct, civil society, routines, patterns of action, and national culture, among others (Levitsky \& Helmke, 2006; North, 1991; Seyoum, 2011). Therefore, Helmke and Levitsky $(2004 ; 2006)$ warn that writers should not treat informal institution as "a residual category" used to describe any behavioural regularity. A behavioural regularity can be viewed as an institution only if it is rooted in shared expectations of appropriate behaviour and rule-bound, that is, not following the pattern will trigger some kind of social sanction (Knight, 1992; Levitsky\&Helmke,2006).

Helmke and Levitsky (2006, pp.13-18) identified four types of informal institutions based on the relationship of formal and informal institutions: complementary, accommodating, competing, and substitutive. Complementary informal institutions are those filling in gaps of formal institutions or urging people to comply with formal rules. Accommodating informal institutions generate incentives for actors to pursue alternative ways without directly violating the formal rules. Competing informal institutions encourage actors to act in ways different from what is expected by the formal constraints; whereas substitutive informal institutions emerge where formal rules are ineffective. Such a classification is based on some hidden assumptions: 1) informal institutions are less important than formal rules; 2) informal institutions only serve as a subsidiary which fills gaps of formal regulations or modifies formal rules; 3) informal institutions emerge only when formal rules are ineffective; and, 4) informal institutions function well only when the formal institutional environment is weak and unsuccessful. However, these hidden assumptions remain controversial given the shortage of empirical evidence. Our study hopes to testify whether such assumptions are tenable or not based on qualitative findings.

Among the various debates on informal institutions, perhaps the most controversial issue is the relationship between the concepts of informal institution and national culture. There are several competing understandings regarding this relationship. Some scholars view national culture as a major content of a country's informal institutions (Pejovich, 1999); some view informal institution and national culture are identical concepts (e.g., Alesina \& Giuliano, 2015; Filiou \& Golesorkhi, 2016). By contrast, some authors believe that these two terms are not synonymous but have a causal relationship (Redding, 2008). For example, Helmke and Levitsky (2004; 2006) argue that informal institutions are norms, whereas national cultures are shared values. Norms rooted in shared beliefs might have a cultural source or have nothing to do with national cultures. National cultures can 
generate, reinforce, or undermine certain unofficial constraints (Helmke \& Levitsky, 2006). A country's national culture is only one of the sources of its informal institutions, political systems and laws are also sources of informal rules. Therefore, countries with a similar national culture (e.g., North and South Korea) may have different informal institutions, constituting noticeable country differences.

Redding (2008) draws a clear line between culture and institution. According to Redding (2008, p.266), culture and institution belong to different realms. Culture is the world of ideas while institutions are the world of order. In other words, culture as logics of action belongs to "the realm of meaning and interpretation", while institutions are "rules of the game in the field of social action" (Redding, 2008, p.261). As "systems of meaning" which help people make sense of their surroundings, culture is at a deep layer and does not directly determine human action. By contrast, as rules, norms, and stable patterns of action, institutions are at the surface and shape human action (Redding, 2008, p.266). For example, reciprocity as a belief is a Chinese business culture, while guanxi (connections) as a behaviour pattern constitutes an informal institution. Reciprocity can be used to justify guanxi, but it is not guanxi. Culture provides meaning for institutions but not institutions. Moreover, culture and institutions can "be a close match or a serious mismatch" (Redding, 2008, p.267). Therefore, understanding cultural differences cannot ensure expatriates of MNEs to adequately understand the informal institutional differences between host and home countries. This might be one of the major reasons why cross-cultural training tends to be less effective and expatriate failure rates remain appallingly high. Understanding institutional differences, especially country differences of informal institutions, is essential for MNEs to correctly interpret host country markets.

\section{INFORMAL INSTITUTIONS AND MNES}

As an integral component of the institutional environment, informal institutions of a host country matter a lot for MNEs operating in that nation. Firstly, without a better understanding of the informal institutions in a host country, an MNE cannot precisely comprehend and interpret its institutional environment. For example, the Constitution of some countries in the world such as the Republic of Philippines and Mexico is very similar to that of the United States (Maddex, 1996). However, given the different informal institutions, the business environment of these countries is more different than we have expected. Even countries such as Canada and the U.S. who share language, historical and legal traditions also have profound differences in terms of informal institutions and business environments (Petersen \& Pedersen, 2002). Moreover, scholars believe that MNE subsidiaries without a better understanding of host country institutions will encounter a higher degree of liabilities of foreignness, i.e., additional costs incurred by foreign firms due to unfamiliarity and discrimination that local firms never face (Mallon \& Fainshmidt, 2017; Zaheer, 1995). Unfamiliarity places MNEs at an informational disadvantage, makes them fail to follow local institutions or violate local expectations unintentionally (Joardar \& Wu, 2011). According to social identity theory, MNEs failing to follow local norms or meet local expectations are more likely to be viewed as outsiders, and are more difficult to earn legitimacy and social support in host countries. Therefore, having a better understanding of local informal institutions is very important for MNEs to avoid embarrassing misunderstanding and missteps (Joardar $\& \mathrm{Wu}, 2011)$. However, the relationship between informal institutions and MNEs has not received enough scholarly attention (Dau et al., 2018; Seyoum,2011).

An extensive literature review reveals that research on the relationship between informal institutions and MNEs has been dominated by two efforts: examining the institutional profile effect and the cultural/psychic/institutional distance effect on foreign direct investment (FDI) and MNE strategies (Dow et al., 2016; Van Hoorn \& Maseland, 2016). Studies focusing on institutional profile effects tend to choose one or several variables to represent the informal institutional environment in a host country. For example, when examining the international expansion of firms, Deng and 
colleagues (2009) identify Guanxi (a firm's network of relationships in a host country) as a dominant informal institution which is significantly associated with the level of FDI.

By contrast, studies focusing on cultural/psychic/institutional distance effects shift their attention from institutional characteristics of host countries to the differences between home and host countries. The early literature focuses on the role of cultural distance in international business (Estrin, Baghdasaryan, \& Meyer,2009). Cultural distance refers to the difference between two countries in terms of cultural values. However, adopting cultural distance as the proxy of cross-country differences has received many criticisms since this construct has both theoretical and methodological limitations (Shenkar,2012). Some writers believe that relying on cultural distance to capture country differences is overly simplistic (Beugelsdijk, Kostova, Kunst, Spadafora, \& van Essen,2018). Shenkar (2012) argues that the cultural distance construct has some hidden assumptions without the support of logic or empirical evidence. One of the hidden assumptions of this construct is that the perceived cultural distance from the home country to the host country is identical to the perceived cultural distance from the host country to the home country of MNEs. However, there is no evidence that people in home and host countries perceive the cultural differences in the same way (Shenkar,2012).

Given the limitations of using culture as the proxy for country differences, the Uppsala internationalization school introduces the concept of psychic distance to capture perceived country differences (Alastair, Coldwell, \& Joosub,2018). Psychic distance refers to "the sum of factors preventing or disturbing the flows of information between firms and markets" (Johanson \& Wiedersheim Paul, 1975, p.308).Such factors include language, culture, religion, education, industrial development, political system, time zones, and the like (Blomkvist \& Drogendijk, 2013). However, psychic distance has been criticized since it is difficult to measure and its usage is arbitrary in nature (Alastair et al., 2018). Moreover, similar with the issue of cultural distance, psychic distance perceptions between countries are also not symmetric (Håkanson, 2014).

Since the mid-1990s, scholars have explored to understand country differences based on the concept of institutional distance that refers to "the extent of difference/similarity between the regulatory, cognitive, and normative institutions of two or more institutional environments" (Kostova, 1996, p.30). Studies on institutional distance and MNEs reveal that institutional distance between countries matters (Jackson \& Deeg, 2008). Research findings demonstrate that the larger the institutional distance between home and host countries, the more difficult for MNEs to obtain local legitimacy and transfer home country practices, and the higher the adaptation cost for MNEs (Cezar \& Escobar, 2015). However, how institutional distance matters is still less clear and has not been well understood (Fortwengel, 2017; Van Hoorn \& Maseland, 2016).

Given that research on the relationship between institutions and MNEs has been dominated by examining the effects of institutional distance on FDI and MNEs, correspondingly, this stream of research has been dominated by variable-based large-N studies where institutions and institutional differences are just examined as abstract "variables" (Fortwengel, 2017; Jackson \& Deeg, 2008).Such a research method might miss "a number of potentially important explanations of how and why exactly the particular institutional distance between two countries matters" (Fortwengel, 2017, p.798). In practice, MNEs are "shaped by the nature and interactions between particular home and host country institutions" (Jackson \& Deeg, 2008, p.541), not just by the institutional differences. The variable-based method might miss important ways in which institutions shape MNEs and MNEs respond to institutional environments. Therefore, more qualitative studies are necessary so as to obtain a better understanding of the relationship between institutions and MNEs (Fortwengel, 2017), especially the interactions between informal institutions and emerging economy MNEs. 


\section{RESEARCH METHOD}

The research questions of this study justify that a qualitative method is appropriate to address our inquiries. Since case studies "represent a methodology that is ideally suited to creating managerially relevant knowledge" (Gibbert, Ruigrok, \& Wicki, 2008, p.1465), this research utilizes a longitudinal, multiple case design to obtain a comprehensive understanding of interactions between informal institutions and MNEs, specifically, the interactions between informal institutions in Australia and EMNEs from China.

Australia is selected as the context of this empirical study for two reasons. First, Australia has been one of the top direct investment destinations for Chinese MNEs in the recent decade. Since 2013, China has overtaken the US and become the largest source of approved foreign investment (The FIRB report, 2017). Second, Australia is different from China on many dimensions such as history, culture, and the economic and political systems. Given these striking differences, it is more likely for Chinese MNEs to encounter unfamiliar informal institutions. Hence, Australia constitutes an ideal context to examine how Chinese MNEs interact with local informal institutions.

Following strategies proposed by Yin (2009) and Patton (2002), case firms were selected based on several criteria. First, the case MNE should be information-rich so that authors "can learn a great deal about matters of importance" (Patton,2002, p.169). Therefore, case firms should be a subsidiary, have both Chinese expatriates and local employees, and have operated in Australia for at least one year so that Chinese expatriates should have some sort of close contact with local governments, communities, and employees, and hence have encountered some kinds of local informal norms, routines, and patterns of action. Second, case firms should come from different industries including mining, manufacturing, and energy industries so as to ensure a representative sample. According to Eisenhardt (1989) and Thomas (2004), when a multiple case design is desirable, four to ten cases are sufficient. Therefore, we chose eight case firms that were denoted by MNE1 to MNE8 to ensure anonymity and the case profiles are presented in Table 1.

Table 1. Profile of Case Chinese MNEs and Interviewees

\begin{tabular}{|c|c|c|c|c|c|c|}
\hline $\begin{array}{l}\text { Case } \\
\text { MNEs }\end{array}$ & Industry & Ownership & $\begin{array}{c}\text { Year of } \\
\text { investment } \\
\text { in Australia }\end{array}$ & $\begin{array}{c}\text { No. of } \\
\text { expatriates }\end{array}$ & $\begin{array}{l}\text { Entry } \\
\text { mode }\end{array}$ & $\begin{array}{c}\text { No. of } \\
\text { interviewees }\end{array}$ \\
\hline MNE1 & Mining & $\begin{array}{l}\text { Listed } \\
\text { company }\end{array}$ & 2006 & 68 & Greenfield & 7 \\
\hline MNE2 & Energy & SOE & 2008 & 12 & Greenfield & 4 \\
\hline MNE3 & $\begin{array}{l}\text { Mineral } \\
\text { resource }\end{array}$ & SOE & 2009 & 15 & $M \& A$ & 3 \\
\hline MNE4 & Mining & POE & 2008 & 10 & Greenfield & 2 \\
\hline MNE5 & Manufacturing & $\begin{array}{l}\text { Listed } \\
\text { company }\end{array}$ & 2007 & 75 & $J V$ & 7 \\
\hline MNE6 & $\begin{array}{l}\text { Coal \& coal } \\
\text { chemical }\end{array}$ & $\begin{array}{l}\text { Listed } \\
\text { company }\end{array}$ & 2004 & 18 & $M \& A$ & 8 \\
\hline MNE7 & Mining & SOE & 2009 & 9 & $M \& A$ & 5 \\
\hline $\begin{array}{l}\text { MNE8 } \\
\text { Total }\end{array}$ & Metallurgical & SOE & 2008 & 16 & Greenfield & $\begin{array}{l}6 \\
42\end{array}$ \\
\hline
\end{tabular}

Notes: SOE: State-owned enterprise; POE: Private-owned enterprise; JV: Joint venture; and M\&A: Mergers and acquisitions. 
Since case studies are often criticized for the lack of methodological rigor (Thomas,2004), this study followed the procedures suggested by Gibbert et al. (2008) to strengthen the validity and reliability of our research. For example, to improve internal validity, multiple interviews were conducted with Chinese expatriates who had worked in their Australian subsidiaries for at least one year. Key informants were interviewed several times face to face or by phone to ensure consistency. Multiple cases and multiple interviews enable us to examine a phenomenon from different perspectives. To enhance construct validity, we exercised due diligence to obtain information from different data sources. We collected data through semi-structured interviews, focus group discussions, and documentation. Online resources including media news were also collected to triangulate our empirical data. The external validity was boosted by our multiple case studies (Gibbert et al., 2008). Procedures were also adopted to address the issue of reliability. We chose a longitudinal research design; prepared a case study protocol to guide our field work; and ensured that at least two researchers participated in interviews and focus group discussions (Eisenhardt, 1989).

Interviews and focus group discussions were conducted from 2012 to 2017 . Within these years, many fieldwork trips were arranged in major cities of Australia (such as Darwin, Perth, Sydney, and Melbourne) for data collection. During the interviews and focus group discussions, we asked participants to describe distinctive local norms, customs, and patterns of action they encountered in Australia; the possible influence on their companies; and how Chinese MNEs handle such local norms and patterned business practices. The interviews and focus group discussions usually ranged from 60 to 120 minutes. A total of 42 Chinese expatriates in the eight case MNEs were interviewed including CEOs, general managers, board members, executive assistants, and heads of departments. The profile of the interviewees is summarized in Table 1.

Data were analyzed utilizing methods proposed by Charmaz (2014). In order to dig out the different layers of meaning in the data, notes of interviews and focus group discussions were coded by at least two researchers following the three steps: initial coding, focused coding, and theoretical coding (Charmaz, 2014). During initial coding, chunks of data were labelled by each researcher based on the meaning identified from the data. After reaching an agreement among researchers about the initial codes, we moved to focused coding to understand the relationships of initial codes and identify dominant categories. During theoretical coding, we identified themes and concepts to capture theoretical connections and ideas. During the coding process, we followed the constant comparative method to understand similarities, differences, and patterns in the data (Charmaz, 2014). To enhance construct validity, we compared our data with the literature to identify a coherent explanation. This usually led to additional data collection and further analysis. Through memo-writing and comparing the themes emerging from the data with the literature, this study identified some informal local institutional characteristics, their effects on MNEs, and strategies of Chinese MNEs towards such informal institutions. The findings and tentative arguments were checked by key informants to enhance the validity and reliability of our research (Maxwell,1996). Table 2 offers examples of our data coding process. 
Table 2. Examples of the Coding Process

\begin{tabular}{|c|c|c|c|}
\hline Examples of interviewees' words & Initial codes & Focused codes & $\begin{array}{c}\text { Theoretical } \\
\text { codes }\end{array}$ \\
\hline $\begin{array}{l}\text {-The government-enterprise } \\
\text { relationship is completely different } \\
\text { from that in China } \\
\text {-Governments have the } \\
\text { responsibility to help companies } \\
\text {-It is impossible for the Australian } \\
\text { government to bend their visa } \\
\text { policies for a foreign firm } \\
\text {-The relationship between } \\
\text { government and companies is } \\
\text { simple }\end{array}$ & $\begin{array}{l}\text { Government- } \\
\text { enterprise } \\
\text { relationship }\end{array}$ & $\begin{array}{l}\text {-The universalistic } \\
\text { government-enterprise } \\
\text { relationship in Australia } \\
\text {-The particularistic } \\
\text { government-enterprise } \\
\text { relationship in China }\end{array}$ & $\begin{array}{l}\text { An informal } \\
\text { institution: the } \\
\text { universalistic } \\
\text { government- } \\
\text { enterprise } \\
\text { relationship }\end{array}$ \\
\hline $\begin{array}{l}\text {-CSR adoption is generally voluntary } \\
\text {-Doing good to earn a good } \\
\text { reputation is not true kindness } \\
\text { - Not enough for an MNE to } \\
\text { contribute the same as local firms }\end{array}$ & CSR & $\begin{array}{l}\text {-The standards-based CSR } \\
\text {-The rights-based CSR }\end{array}$ & $\begin{array}{l}\text { An informal } \\
\text { institution: the } \\
\text { rights-based } \\
\text { CSR }\end{array}$ \\
\hline $\begin{array}{l}\text { - Chinese workers are ready to work } \\
\text { overtime } \\
\text {-Working beyond the normal } \\
\text { working hours is the exception, not } \\
\text { the norm } \\
\text {-Stop working immediately when it } \\
\text { is time for them to go home } \\
\text {-Local workers refuse working extra } \\
\text { minutes, let alone extra hours }\end{array}$ & $\begin{array}{l}\text { Work } \\
\text { Overtime }\end{array}$ & $\begin{array}{l}\text {-Different attitudes } \\
\text { towards working } \\
\text { overtime \& work-life } \\
\text { balance } \\
\text { - Companies as the family } \\
\text { of employees } \\
\text {-Different work norms }\end{array}$ & $\begin{array}{l}\text { An informal } \\
\text { institution: the } \\
\text { work-life } \\
\text { balance } \\
\text { preference and } \\
\text { the 'zero- } \\
\text { minute } \\
\text { overtime' } \\
\text { norm }\end{array}$ \\
\hline
\end{tabular}

\section{AUSTRALIAN INFORMAL INSTITUTIONS PERCEIVED BY CHINESE MNES}

MNEs may encounter various socially endorsed norms of behaviour in host countries. To make our research manageable, this paper only focused on some major local informal institutional characteristics that shape the relationship between Chinese MNEs and key Australian stakeholders such as government, local communities, and employees. Apart from formal rules such as labour regulations and environment laws, the tacit socially shared norms also shape the expectations and behaviour of MNEs and their local stakeholders. The following are some distinctive informal institutions identified by this research.

\section{THE UNIVERSALISTIC GOVERNMENT-ENTERPRISE RELATIONSHIP}

A universalistic government-enterprise relationship refers to a rule-based and impersonal relationship where regulations, in any situations, are applied to all firms without much flexibility. It is the opposite of a particularistic government-enterprise relationship which can be found in China where policy implementation might be shaped by specific situations and relationships. Since such a universalistic government-enterprise relationship is prevalent and widely accepted as appropriate and desirable in 
Australia, it can be considered as institutional. Government officials failing to follow such a universalistic principle may invite public criticism. Such a government-enterprise relationship has its cultural sources since China has a particularistic national culture whereas Australia has a universalistic national culture (Stone \& Stone-Romero, 2008). Such a norm also has its roots in official regulations and laws and thus it is easily mistaken for a formal institution. The difference in terms of the government-enterprise relationship is one of major institutional distinctions between China and Australia. The executive chairman of MNE1 described how such a universalistic norm of governmententerprise relationship looked like and influenced the implementation of government policies,

According to the official regulations and laws of China and Australia, government and enterprises should have an impersonal relationship in both countries. However, I find the government-enterprise relationship in Australia is completely different [from that in China]. In China, government has the responsibility to help companies within their jurisdiction. If a company encounters serious difficulties, it is natural for them to turn to government for help. Local governments are also happy to help them so as to boost the local economy. But in Australia, government agencies only formulate and follow rules. It is impossible for them to make an exception to rules in order to resolve issues of specific companies [...] Our project has suffered from serious delays and overspends in recent years. So we appeal to the Australian government, hoping it allows us to bring more Chinese skilled workers to speed up construction and reduce costs. However, they refuse to do so.

This sentiment was echoed by the deputy manager of MNE7,

One of our projects is located around five hundred miles from here [a large Australian city]. The village life of our expatriates working there is too harsh. So the parent company decides to send several Chinese chefs there to improve the quality of life. However, the chefs cannot get a visa since the Australian government insists that these chefs should take an IELTS test. Is a good command of English necessary for such a position? Is it possible that a Chinese chef with English skills is willing to work in that remote area? However, it is impossible for the Australian government to bend their policies for a firm. In China, the response of the government will be different... The government will help us following the norm which fixing special issues with special methods.

\section{THE RIGHTS-BASED CORPORATE SOCIAL RESPONSIBILITY (CSR)}

According to McWilliams and Siegel (2000, p.117), CSR refers to "voluntary corporate practices aimed at furthering social goods, beyond the interest of the firm and that which is required by law". Rathert (2016, p.860) groups CSR into two distinct categories: standards-based CSR which firms used to meet the minimum legal requirements, and rights-based CSR which firms used to address expectations of stakeholders and defines the rights-based CSR as "a set of discretionary social practices addressing stakeholder expectations related to the organizational implementation of legal rules and social norms". Although various definitions of CSR emphasize its voluntary nature as "a form of private governance" (Rathert, 2016, p.860), CSR nowadays has actually, in many developed economies including Australia, evolved into a strong informal institution that shape social expectations of stakeholders regarding companies, especially MNEs. MNEs nowadays are facing more pressure to engage in CSR initiatives in host countries, particularly in countries with a strong institutional environment which authorizes stakeholders to 'demand' CSR behaviour from companies. Consequently, MNEs are required to undertake more CSR activities to meet the expectations of local 
stakeholders so as to obtain legitimacy. Many MNEs utilize CSR adoption as a signaling strategy to demonstrate their commitment to local stakeholders and reduce the liability of foreignness (Campbell, 2007; Rathert, 2016). When discussing the CSR adoption of Chinese MNEs, one manager of MNE4 explained,

In China, CSR adoption is generally voluntary for companies without a high-profile name. But in Australia, everyone in the local community knows that you are a foreign company and wants us to contribute more. In order to build a good relationship [with the local community], foreign companies usually conduct more CSR activities than local firms [...] It is not enough for a foreign company contributes just the same as a local company if it wants to earn enough local support.

The deputy manager of MNE5 offered a similar comment,

In China, usually companies deal only with local governments, not the local community. But in Australia, a foreign company must make the local community happy, not the government. In order to earn local support, our company has invested a lot in the regional health, education, and youth programs [... ] Local people have a high expectation [of foreign firms]. Some people often say that Chinese companies have money and should help us do this and do that. However, we are a commercial company and must survive economically [... ] what is the scope of the social responsibility for foreign firms?

\section{THE NORM OF ZERO-MINUTE OVERTIME}

Shaped by the collectivist culture and the paternalist tradition, managers in China hope employees to treat the company as their family and go all out for their work. Working overtime tends to be viewed as an indicator of organizational commitment and is quite common in the Chinese workplace. Apart from employing overtime work as a strategy of impression management, Chinese employees usually cannot refuse to work overtime if managers ask them to do so, although the government regulations in China also have strict limits on overtime. If they are paid for overtime work, many Chinese employees are happy to work overtime.

By contrast, in Australia, working overtime is less common. This is not the result of the Australian formal institutions since labor regulations in both countries set strict limits on overtime. It is mainly the work-life balance preference shared by most Australian organizations and workers. This does not mean that Australian people never work extra time, but working beyond the normal working hours is the exception, not the norm. Chinese expatriates tend to be very impressed by this work norm. One board officer of MNE1 told the researchers,

When our company prepared the feasibility report of this Australian project, the team ignored the local work norms and assumed that Australian employees are flexible as Chinese workers in terms of working hours and are ready to work overtime. However, we soon find that local workers refuse to work extra minutes, let alone extra hours, even if the project has been serious delayed and we promise to pay them at a higher rate.

The Office manager in MNE3 felt the same way,

The working hours of our company are from gam to 5pm. If you visit an office of local employees at, say, 5:05pm, you usually cannot find anyone [... Y You can only find Chinese expatriates in the company after business hours [... I I heard a story that local workers are making some pre-made 
parts using cement and sand. They stop working immediately when it is time for them to go home, leaving some pre-made cement parts unfinished and hence ruined. Although it is estimated that they can finish the job if they work overtime for just five to twenty minutes, they refuse to do so. [...] I also read a news report that a local employee sued her boss for 500 thousand dollars because the boss made her work overtime for one to six minutes for around twenty times during her six-month job. It is unbelievable in China.

Such a norm of 'zero-minute overtime' in the Australian workplace cannot be explained just by labor regulations. It is a workplace routine that local employees strictly protect the boundary of work and life.

\section{SAFETY AND HEALTH FIRST IN THE WORKPLACE, NOT EFFICIENCY}

All Chinese expatriates interviewed were impressed by how work is carried out in a safe manner in the Australian workplace. In most cases, Australian employees try their best to carry out responsibilities in a safe and secure way, although efficiency could be sacrificed. Giving workplace safety and health the highest priority has become a workplace convention in Australia. On the surface, this is because Australia has comprehensive work health and safety (WHS) laws. However, many countries have similar regulations but have not achieved a similar level of workplace safety. As one manager of MNE6 commented,

It is difficult to say that safety regulations in China are not comprehensive and strict. Many Chinese companies also attach great importance to workplace safety but many of them have failed to minimize unsafe workplace behaviour. Safety managers in China often wonder why unsafe behaviour cannot be eliminated in their companies.

The Managing Director of MNE2 was impressed by this Australian work norm,

The Australian culture seems incredibly relaxed and Australian people are seemingly very laid back[...] However, in the workplace, they are meticulous workers and extraordinarily professional, prefer quality [over quantity], and strictly follow various regulations [... ] A project which can be done within one year in China might take three years in Australia, but the quality is good and the accident rate is extremely low.

One manager of MNE5 explained his judgment,

I have been thinking about this for a long time. The good WHS in Australia is not just the result of laws and regulations enforced by government. The major reason is that the whole society, not just government, has taken workplace health and safety seriously [... ] Apart from WHS laws, every industry has codes of conduct to promote best practices and guide employees how to work safely. Every organization also has health and well-being programs of their own to ensure the health and safety of employees. These codes of conduct and organizational programs are not legally enforceable, but people follow them strictly [...] The WHS laws are not just laws; they have developed into routines and habits of Australian organizations and employees.

The four informal institutions identified in this study have their cultural or legal roots. They are derived from and shaped by national culture or regulations. Therefore, they are easily viewed as cultural or legal characteristics. However, according to Redding (2008), culture belongs to "the world 
of ideas" which helps people make sense of their surroundings but does not determine behaviour, while institutions belong to "the world of order" and directly determine human action. These identified characteristics have definitely gone beyond "the realm of ideas" and turned into shared ways of behaving and accepted "rules of the game" in Australia. In this study, universalism as a belief constitutes a cultural dimension. It generates and justifies the impersonal and universalistic government-enterprise relationship which as a behaviour pattern constitutes an informal institution. Similarly, work-life balance as an idea generates and justifies the zero-minute overtime norm; while the no-overtime norm as a behaviour pattern constitutes an informal institution which directly determines workplace behaviour. The safety and health first in the workplace and the rights-based CSR are not just values and beliefs but have become accepted pattered behaviour. It is necessary to single out such informal institutions; otherwise they might be ignored or marginalised in studies on national cultures and the cross-cultural training programs of MNEs.

\section{STRATEGIES OF CHINESE EXPATRIATES AND MNES TOWARDS LOCAL INFORMAL INSTITUTIONS}

The four informal institutions identified in this study lay the foundation for our analysis of the coping strategies of Chinese MNEs and their expatriates. How to deal with informal institutional differences between home and host countries to avoid misunderstanding and missteps is a challenge for Chinese expatriates and MNEs without rich international experience. In the fieldwork, we found that local institutional characteristics had significantly shaped the behaviour of Chinese expatriates and strategies of Chinese MNEs. Confronting local norms and customs that influence the expectations and behaviour of stakeholders, Chinese expatriates and MNEs had gradually become less confused and developed some strategies to address such institutional differences.

\section{FROM COMPLAINING TO RESPECTING DIFFERENCES}

Our longitudinal study had identified a clear change of the attitude of Chinese expatriates towards local norms. In the early interviews, it was more likely to hear complaints from Chinese managers, especially those newcomers. Later interviews indicated that most informants had changed their attitude and developed positive views about different local work norms. As the executive chairman of MNE1 explained,

In the beginning, there are some complaints that the Australian government is indifferent towards foreign firms and refuses to help us out. Now we understand that such a governmententerprise relationship is just different from ours and not entirely bad. [In China], a good relationship with government agencies is very important for companies. If a company is important and has a good relationship with a government agency, sometimes a government agency might make an exception for the company. Therefore, companies in China have invested a lot of time and energy to build relationships with government officials [...] But in Australia, things are simple. You know government agencies will never change rules to help your company. There is no need for companies to invest much time and energy to build relationships with government. This sometimes makes our life easier. 
An assistant manager of MNE3 also expressed her understanding of the norm of zero-minute overtime and did not agree to link working overtime with the level of organizational commitment,

I view it just as a different work norm. Chinese companies usually hope employees to treat the company as their family and invest all their time into work, including their spare time when needed [... ] People here pursue work-life balance and quality of life [...] This just reflects the difference in terms of how central work is [in people's life]. It is difficult to say which one is better.

Our fieldwork found that most Chinese expatriates had gradually gotten used to the country differences and handle the differences in a positive way. One method adopted by Chinese expatriates was to communicate honestly since they believed that communication is king. Several expatriates interviewed told the researchers that they handle country differences very well through open and honest communication, as the manager of $\mathrm{MNE}_{3}$ commented,

Nowadays you can find institutional differences anywhere; even within one large country. [... ] I do not consider such differences are challenging and difficult to deal with. For me, if I do not know or understand something, I just tell local colleagues that I do not know this as I am a foreigner and ask them to give me suggestions.

\section{FROM SUSPICION TO LEARNING WITH AN OPEN MIND}

In the early discussions with informants, we found that some Chinese expatriate managers did not fully agree with certain local work norms. They doubted whether such work norms were sustainable since they seemed to be detrimental to efficiency. In the interviews of the following years, we found that the doubt had largely disappeared and, in some cases, Chinese MNEs wanted to implant the same work norms in their parent companies. As one mine manager of MNE6 explained,

We have talked about many country differences between China and Australia [...] To speak frankly, in the beginning, we do not like the no-overtime norm and some work procedures followed by local employees. They seem to be too rigid and lack efficiency. But now our patent company is learning these workplace norms, they also want to turn the safety regulations into routines of all employees to minimize the unsafe individual behaviour in the workplace.

Our fieldwork found that all case firms had attached importance to learning. Headquarters often sent staff to their Australian subsidiaries for training and accumulating international experience; subsidiaries also arranged local staff to work or attend training programs at headquarters. As a board officer of MNE6 had commented,

From the perspective of efficiency, rigid regulations might be not desirable. But sometimes hypercorrection is necessary [...] It is good practice not to cut corners and bend safety procedures for efficiency. We like these workplace norms now and promote them in China [...] The best practices of WHS management in this subsidiary have significantly improved the safety management of our parent company in China. 


\section{FROM GOVERNMENT-ORIENTATION TO COMMUNITY-ORIENTATION}

Research findings revealed that case MNEs also tried to adapt their behaviour and business strategies to the local institutional environment. Chinese expatriates interviewed told the researchers that their companies did not invest much time and energy to build a close relationship with government agencies in Australia when they understood the nature of government-enterprise relationship. Instead, they had paid more attention to building a good relationship with local communities. The manager of MNE4 told the researchers:

In China, all companies want to build a good relationship with local government agencies. When they meet difficulties, they tend to turn to government first. But in Australia, a good relationship with government does not mean a good relationship with local communities, whereas making local communities happy is more important. Therefore, our company has paid more attention to the relationship with local communities.

The manager of MNE2 echoed the same idea,

In Australia, social license is most important. Our company has made every effort to obtain full social support. A good relationship with local communities is earned by your local contributions, the local government cannot help you get this.

\section{FROM SILENT CSR TO OPEN CSR}

According to the Chinese culture, people should engage in charitable activities anonymously, that is, doing good deeds without leaving one's name. Otherwise, you are viewed as self-interested since your charitable behavior might be only for your own good and doing good to earn a good reputation is not true kindness. Influenced by such a notion, case Chinese MNEs tended to engage in CSR activities silently and ignored to publicize their CSR achievements. In the interviews of recent years, we found that Chinese MNEs had emphasized the importance of letting others know their CSR performance and openly disseminated their CSR programs. One manager in MNE6told the researchers:

In the beginning, we do not realize that we should publicize our CSR programs for corporate reputation. We think if we do so, it is not a true CSR effort since you are actually investing in your corporate reputation [...] However, when local people demand that foreign companies must contribute to the local community, you have to let everyone know what your company has contributed so as to obtain social support. [...] So, we learn from other companies and release a sustainability report every year to make public all our CSR activities.

The CFO of MNE8 also told the researchers,

It is not good practice for Chinese MNEs not to publicize their CSR contributions for good reputation. Chinese firms have not been well understood in Western countries. We should let people know that Chinese firms are also responsible investors and are contributing to local communities [... ] Therefore, our company publicize any CSR programs through our website and media. 


\section{FROM THE CHINESE WAY TO THE BEST-FIT STRATEGY}

Interview findings revealed that case Chinese MNEs were confident about their business models since the models were proved successful in the Chinese market. Therefore, some case MNEs such as MNE1, MNE2, and MNE6 had initially tried to transfer their business models to their Australian subsidiaries and run these firms in the Chinese way. They soon found that this was not good practice given the huge difference between the Chinese and Australian workplaces. Therefore, these companies started to adopt business models that best fit the local environment and manage subsidiary locally. One board officer of MNE1 described the process to the researchers,

Our firm has bought several companies through acquisition in Australia. In the beginning, the parent company sent many managers from China to cover key positions and attempted to run the subunits in the Chinese way [... ] However, using too many expatriates has led to inefficiency $[\ldots]$ Therefore, the head office has changed the policy, localized key positions and run them in the same way as other Australian companies.

\section{DISCUSSION AND CONCLUSIONS}

This study seeks to explore host-country informal institutions that shape the behaviour and strategies of expatriates and MNEs. Four local informal institutions were discussed, including the universalistic and impersonal government-enterprise relationship, the rights-based CSR, the zero-minute overtime norm, and giving health and safety the highest priority in the workplace. These norms are prevalent and widely accepted as appropriate and desirable patterns of action in Australia, and hence can be viewed as institutional. Although these norms shape the expectations of local stakeholders and the relationship of MNEs with government, local communities, and employees, they are tacit and taken for granted. MNEs failing to follow these conventions may invite public criticism or social sanction. This study also examines the potential influences of informal institutions on the behaviour of MNEs, and how Chinese expatriates and MNEs deal with the informal institutional differences between China and Australia.

Our findings demonstrate that informal institutions of host countries, if not more significant, are as important as the host-country formal institutions and national cultures for MNEs. Informal institutions structure social expectations and attitudes, shape behaviour and management styles, and influence interactions and relationships. Without a correct understanding of informal institutions, an MNE could not comprehend the local institutional environment accurately. A better understanding of informal institutions in host countries can help MNEs make the right decision and avoid embarrassing misunderstanding and missteps.

This research makes several theoretical contributions to the literature. First, it is among the limited studies analyzing Australian informal institutions and examining the interaction between MNEs and informal institutional characteristics based on first-hand qualitative evidence.

Second, this research enriches our understanding of the relationship between formal and informal institutions. Helmke and Levitsky (2006, pp.13-18) identified four types of relationship between formal and informal institutions: complementary, accommodating, competing, and substitutive. As discussed earlier, such an understanding is based on some hidden assumptions: informal institutions are less important than formal rules; they only serve as a subsidiary that fills gaps of formal regulations or modifies formal rules; informal institutions emerge only when formal rules are ineffective; and informal institutions function well only when the formal institutional environment is weak and unsuccessful. However, our study demonstrates that informal institutions can emerge in a strong institutional environment. For example, all the four informal institutions identified in this study emerge 
as results of a strong regulative environment. Without the support of formal regulations, no one knows whether these informal norms can emerge and function well or not. Conventional wisdom tends to assume informal institutions complement and enhance formal institutions, not vice versa. This research reveals a new relationship between formal and informal institutions, that is, strong formal institutions foster the emergence of similar and related informal institutions. Moreover, our study demonstrates that the emergence of informal institutions may encourage people to comply with similar and related formal institutions. For instance, without the norm of prioritizing workplace health and safety, the Australian Work Health and Safety Act might have not been strictly followed by local employees. Therefore, formal institutions should be sublimated into informal norms to ensure a high level of compliance. Sublimation here refers to the process of internalizing legal requirements into taken-for-granted patterns of action through socialization.

Third, this study empirically identified and examined some informal institutions, which advances our understanding about informal institutions and the relationship between informal institution and national culture. Our analysis reveals that informal institution and culture are not synonymous. Culture generates and justifies informal institutions. Culture is one source, but not the only source, of informal institutions.

This study has implications for government, MNEs, cross-cultural educators, and MNE scholars. For government, the relationships between formal and informal institutions can help government improve the enforcement of formal rules. Given that formal rules cannot function well without the support of informal institutions, and informal norms can emerge from a strong regulative environment, government can improve the effectiveness of formal rules through influencing or cultivating informal norms. For example, in order to help companies manage workplace health and safety effectively, the Safe Work Australia, a government agency, formulates various Model Codes of Practice to guide people to handle WHS issues. These codes of practice are not legally enforceable but have fostered the Australian society to form some WHS routines beyond the requirements of WHS laws.

For MNEs and cross-cultural educators, our research demonstrates that informal institution and culture are not the same, and informal institutional characteristics of host countries shape the social expectations and behaviour of local stakeholders. Therefore, MNEs and cross-cultural educators should pay enough attention to such informal constraints, not just focus on the national culture and formal institutions of the host country. In addition, our research also helps new investors understand some major Australian informal institutional characteristics and generate strategies to address the complex local institutional environment.

For MNE scholars, our study demonstrates that qualitative research can provide rich information regarding how informal institutions and MNEs interact in a host country. Exploring interactions of informal institutional characteristics and MNEs based on qualitative data can enrich and deepen our understanding of the institutional environment and the behaviour of MNEs. A longitudinal research design will enable researchers to capture the pattern and attitude changes.

The major limitation of this study is that it is mainly based on perceptions of Chinese expatriates. To enrich and triangulate data, local managers, employees, government agencies and local communities should also be interviewed. Future research can improve the research design and conduct interviews more comprehensively. Interactions between MNEs and local institutional characteristics are a rich source for scholars. Future studies can identify more informal institutions and more firm-level strategies of MNEs addressing country institutional differences. 


\section{REFERENCES}

Alastair, D., Coldwell, D., \& Joosub, T. (2018). The FDI psychic distance paradox: Myth or reality? Journal of Business and Retail Management Research, 12 (2), 38-48.

Allen, M.M., Allen, M.L., \& Lange, K. (2018). Institutions and the diversity and prevalence of multinationals' knowledge-augmenting subsidiaries. British Journal of Management, 29, 483496.

Alesina, A., \& Giuliano, P. (2015). Culture and institutions. Journal of Economic Literature, 53(4), 898944.

Beugelsdijk, S., Kostova, T., Kunst, V.E., Spadafora, E., \& van Essen, M. (2018). Cultural distance and firm internationalization: A meta-analytical review and theoretical implications. Journal of Management, 44(1), 89-130.

Blomkvist, K., \& Drogendijk, R. (2013). The impact of psychic distance on Chinese outward foreign direct investments. Management International Review, 53(5), 659-686.

Cezar, R., \& Escobar, O.R. (2015). Institutional distance and foreign direct investment. Review of World Economics, 151(4), 713-733.

Campbell, J.L. (2007). Why would corporations behave in socially responsible ways? An institutional theory of corporate social responsibility. Academy of Manage Review, 32(3), 946-967.

Charmaz, K. (2014). Constructing grounded theory. London: Sage.

Dau, L.A., Chacar, A., Lyles, M., \& Li, J.T. (2018). Call for papers: Informal institutions and international Business. Journal of International Business Studies. Retrieved from https://globaledge.msu.edu/academy/announcements/call-for-papers/63764

Deng, F.J., Huang, L.Y., Carraher, S.M., \& Duan, J. (2009). International expansion of family firms: An integrative framework using Taiwanese manufacturers. Academy of Entrepreneurship Journal, 15(1), 25-42.

Dow, D., Cuypers, I.R., \& Ertug, G. (2016). The effects of within-country linguistic and religious diversity on foreign acquisitions. Journal of International Business Studies, 47(3), 319-346.

Eisenhardt, K.M. (1989). Building theories from case study research. Academy of Management Review,14, 532-550.

Estrin, S., Baghdasaryan, D., \& Meyer, K.E. (2009). The impact of institutional and human resource distance on international entry strategies. Journal of Management Studies, 46(7), 1171-1196.

Filiou, D., \& Golesorkhi, S. (2016). Influence of institutional differences on firm innovation from international alliances. Long Range Planning, 49, 129-144.

FIRB (29 March 2017). 2015-16 Annual Report. The Foreign Investment Review Board. Canberra, Australia. Retrieved from https://firb.gov.au/about-firb/publications/2015-16-annual-report

Fortwengel, J. (2017). Understanding when MNCs can overcome institutional distance: A research agenda. Management International Review, 57(6), 793-814.

Gibbert, M., Ruigrok, W., \& Wicki, B. (2008). What passes as a rigorous case study? Strategic Management Journal, 29, 1465-1474.

Håkanson, L. (2014). The role of psychic distance in international trade: A longitudinal analysis. International Marketing Review, 31(3), 210-236.

Heilein, R. (1961). Stranger in a strange land. New York: Putnam Publishing Group.

Helmke, G., \& Levitsky, S. (2004). Informal institutions and comparative politics: A research agenda. Perspectives on Politics, 2(4), 725-740.

Helmke, G., \& Levitsky, S. (2006). Introduction. In G. Helmke \& S. Levitsky, (Eds.), Informal institutions and democracy: Lessons from Latin America (pp.285-289). Baltimore, Maryland: Johns Hopkins University Press. 
Henisz, W., \& Swaminathan, A. (2008). Institutions and international business. Journal of International Business Studies, 39, 537-539.

Huntington, S. (1969). Political order in changing societies. New Haven, CT: Yale University Press

Jackson, G., \& Deeg, R. (2008). Comparing capitalisms: Understanding institutional diversity and implications for international business. Journal of International Business Studies, 39, 540-561.

Joardar, A., \& Wu, S. (2011). Examining the dual forces of individual entrepreneurial orientation and liability of foreignness on international entrepreneurs. Canadian Journal of Administrative Science, 28(3), 328-340.

Johanson, J., \& Wiedersheim-Paul, F. (1975). The internationalization of the firm - four Swedish cases. Journal of Management Studies, 12(3), 305-322.

Klossek, A., Linke, B., \& Nippa, M. (2012). Chinese enterprises in Germany: Establishment modes and strategies to mitigate the liability of foreignness. Journal of World Business, 47(1), 35-44.

Knight, J. (1992). Institutions and social conflict. New York: Cambridge University Press.

Kostova, T. (1996). Success of the transnational transfer of organizational practices within multinational companies. Unpublished manuscript, University of Minnesota, Minneapolis.

Levitsky, S., \& Helmke, G. (2006). Informal institutions and democracy: Lessons from Latin America. Baltimore, Maryland: Johns Hopkins University Press.

Luo, Y., \& Zhang, H. (2016). Emerging market MNEs: Qualitative review and theoretical directions. Journal of International Management, 22(4), 333-350.

McWilliams, A., \& Siegel, D. (2000). Corporate social responsibility and financial performance: Correlation or misspecification? Strategic Management Journal, 21(5), 603-609.

Maddex, R.L. (1996). Constitutions of the world. London: Routledge.

Mallon, M.R., \& Fainshmidt, S. (2017). Assets of foreignness: A theoretical integration and agenda for future research. Journal of International Management, 23(1), 43-55.

Maxwell, J.A. (1996). Qualitative research design. Newbury Park, CA: Sage.

North, D.C. (1990). Institutions, institutional change and economic performance. Cambridge, U.K.: Cambridge University Press.

North, D.C. (1991). Institutions. Journal of Economic Perspectives, 5(1),97-112.

Orr, R.J., \& Scott, W.R. (2008). Institutional exceptions on global projects: A process model. Journal of International Management, 39(4), 562-588.

Ostrom, E. (2005). Understanding institutional diversity. Princeton, New Jersey: Princeton University Press.

Patton, M. (2002). Qualitative research and evaluation methods. Thousand Oaks, CA: Sage.

Pejovich, S. (1999). The effects of the interaction of formal and informal institutions on social stability and economic development. Journal of Markets Morality, 2(2), 164-181.

Petersen, B., \& Pedersen, T. (2002). Coping with liability of foreignness: Different learning engagements of entrant firms. Journal of International Management, 8(3), 339-350.

Rathert, N. (2016). Strategies of legitimation: MNEs and the adoption of CSR in response to hostcountry institutions, Journal of International Business Studies, 47(7), 858-879.

Redding, G. (2008). Separating culture from institutions: The use of semantic spaces as a conceptual domain and the case of China. Management and Organization Review, 4(2), 257-89.

Regnér, P., \& Edman, J. (2014). MNE institutional advantage: How subunits shape, transpose and evade host country institutions. Journal of International Business Studies, 45(3), 275-302.

Sartor, M.A., \& Beamish, P.W. (2014). Offshoring innovation to emerging markets: Organizational control and informal institutional distance. Journal of International Business Studies, 45(9), 1072-1095.

Scott, W.R. (2013). Institutions and organizations: Ideas, interests, and identities. Thousand Oaks, CA: Sage. 
Seyoum, B. (2011). Informal institutions and foreign direct investment. Journal of Economic Issues, 45(4), 917-940.

Shenkar, O. (2012). Cultural distance revisited: Towards a more rigorous conceptualization and measurement of cultural differences. Journal of International Business Studies, 43(1), 1-11.

Stone, D., \& Stone-Romero, E. (2008). The influence of culture on human resource management processes and practices. New York: Psychology Press.

Thomas, A.B. (2004). Research skills for management studies. London: Routledge.

Yin, R.K. (2009). Case study research: Design and methods. Thousand Oaks, CA: Sage.

Van Hoorn, A., \& Maseland, R. (2016). How institutions matter for international business: Institutional distance effects vs. institutional profile effects. Journal of International Business Studies, 47(3), 374-381.

Wang, H., Lu, W., Soderlund, J., \& Chen, K. (2018). The interplay between formal and informal institutions in projects: A social network analysis. Project Management Journal, 49(4), 20-35.

Zaheer, S. (1995). Overcoming the liability of foreignness. Academy of Management Journal, 38(2), 341363.

Zhang, M. M. (2016). The institution of hukou-based social exclusion in contemporary China and strategies of multinationals. New York: Nova Science Publishers. 